\title{
DAMPAK PANDEMI COVID-19 PADA LAYANAN KESEHATAN IBU DAN ANAK (KIA) DI KOTA DEPOK
}

\section{THE IMPACT OF COVID-19 PANDEMIC ON MATERNAL AND CHILD HEALTH (MCH) SERVICES IN DEPOK CITY}

\author{
Rizki Yulia $^{1}$, Ahmad Syafiq ${ }^{2 *}$, Hadi Pratomo ${ }^{1}$, Nur Eulis Sulastri ${ }^{3}$ \\ ${ }^{1}$ Prodi Ilmu Kesehatan Masyarakat Fakultas Kesehatan Masyarakat Universitas Indonesia, Pondok \\ Cina, 12345, Kota Depok, Jawa Barat, Indonesia \\ ${ }^{2}$ Pusat Kajian Gizi dan Kesehatan Fakultas Kesehatan Masyarakat Universitas Indonesia, Pondok \\ Cina, 12345, Kota Depok, Jawa Barat, Indonesia \\ ${ }^{3}$ Dinas Kesehatan Kota Depok, Jl. Margonda Raya No.54, 16431, Kota Depok, Jawa Barat, Indonesia \\ *email: a-syafiq@ui.ac.id
}

\begin{abstract}
Depok City has implemented a social distancing policy which has an impact on MCH services. The objectives is assessing the impact of the COVID-19 pandemic on MCH services and analyzing the MCH services that are most affected during the COVID-19 pandemic. The study was carried out in an integrated program of "e-Monev for Restoring MCH, Family Planning and Nutrition Services from the Impact of the COVID-19 Pandemic" conducted by the Directorate of Family Health, Ministry of Health of the Republic of Indonesia. MCH services are classified into 4 groups, namely: pregnancy services $K 1$, pregnancy services $K 4$, delivery services at health facilities, and monitoring of growth and development at Posyandu (Integrated Healthcare Centre). The study used quantitative and qualitative approaches. Quantitative data obtained from monthly visit data for the period January to September 2019 and 2020 from the Depok City Health Office. Qualitative data were collected through in-depth interviews using the Zoom application and e-survey from Google Forms application. The results showed a decrease in almost all of January to September, unless there was increase in K1 coverage on July is $0.48 \%$ and August is 2.18\%; an increase in K4 coverage on July by $2.1 \%$ and August by $2.88 \%$; delivery assistance only in July which experienced an increase (3.21\%); the attainment of growth and development monitoring which experienced an increase (15.08\%) are only on August. The conclusion The coverage of K1, K4, delivery in health facilities, and the monitoring of growth and development of children under five have decreased. MCH services most affected by COVID-19 pandemic is monitoring of growth and development of children under five.
\end{abstract}

Keywords: COVID-19, impact, MCH Services, pandemic

\begin{abstract}
Abstrak
Kota Depok menerapkan kebijakan PSBB yang berdampak pada pelayanan KIA. Adanya pandemi memperberat tantangan dalam memberikan pelayanan sehingga terdapat kekhawatiran terancamnya asuhan pada ibu dan anak. Tujuan penelitian ini adalah menilai dampak pandemi COVID-19 terhadap layanan KIA dan menganalisis layanan KIA yang paling terpengaruh dalam masa pandemi COVID-19. Studi dilakukan terintegrasi program "e-Monev untuk Pemulihan Pelayanan KIA, KB dan Gizi dari Dampak Pandemi COVID-19" yang dilaksanakan Direktorat Kesehatan Keluarga, Ditjen Kesehatan Masyarakat, Kementerian Kesehatan RI. Pelayanan KIA dikelompokan menjadi 4 yaitu: layanan kehamilan K1, layanan kehamilan K4, layanan persalinan di fasilitas kesehatan, dan pemantauan pertumbuhan dan perkembangan di Posyandu. Studi menggunakan pendekatan kuantitatif dan kualitatif. Data kuantitatif menggunakan data kunjungan bulanan pada periode Januari-September tahun 2019 dan 2020 dari Dinkes Kota Depok. Data kualitatif dikumpulkan melalui wawancara mendalam menggunakan aplikasi zoom meeting dan e-survey menggunakan aplikasi Google Formulir. Hasil
\end{abstract}


penelitian ini menunjukkan adanya penurunan hampir pada seluruh Januari hingga September, kecuali terdapat kenaikan cakupan K1 bulan Juli sebesar 0,48\% dan Agustus sebesar 2,18\%; kenaikan cakupan K4 bulan Juli sebesar 2,1\% dan Agustus sebesar 2,88\%; pertolongan persalinan hanya bulan Juli yang mengalami kenaikan (3.21\%); capaian pemantauan tumbuh kembang hanya bulan Agustus yang mengalami kenaikan $(15,08 \%)$. Kesimpulan dari studi ini adalah terjadi penurunan pada cakupan K1 dan K4, cakupan persalinan di fasilitas kesehatan dan pemantauan tumbuh kembang balita. Layanan KIA yang paling terpengaruh pada pandemi COVID-19 adalah pemantauan tumbuh kembang balita.

Kata Kunci: COVID-19, dampak, layanan KIA, pandemi

\section{PENDAHULUAN}

Corona Virus Disease 2019 (COVID-19) pertama kali dilaporkan di Kota Depok, Indonesia, pada tanggal 02 Maret 2020 (Djalante et al. 2020). Pemerintah Kota (Pemkot) Depok melalui Gugus Tugas Percepatan Penanganan COVID-19 Kota Depok menetapkan bahwa 18 Maret hingga 29 Mei 2020 sebagai Tanggap Darurat Bencana melalui Surat Keputusan (SK) Wali Kota Depok Nomor 360/137/Kpts/DPKP/Huk/2020 tentang Penetapan Status Tanggap Darurat Bencana COVID-19 di Kota Depok. Berdasarkan SK tersebut maka masyarakat Kota Depok dihimbau untuk tidak melakukan kegiatan yang melibatkan banyak orang, menutup sementara tempat umum dan menunda pelaksanaan kegiatan resepsi pernikahan. Kebijakan tersebut juga memberikan dampak pada pelaksanaan pelayanan kesehatan masyarakat, salah satunya yaitu pelayanan Kesehatan Ibu dan Anak (KIA) (Baumann et al. 2021, Moyer et al. 2020, Saputri et al. 2020).

Tidak dapat dipungkiri, saat pandemi COVID-19 menyebar, pelayanan kesehatan memiliki beban tambahan dalam melakukan skrining, pengujian laboratorium dan perawatan intensif (Lindholt and Søgaard 2020, Vintzileos et al. 2020) Studi yang dilakukan di Italia menunjukan jika kebijakan untuk menangani pandemi COVID-19 seperti pelaksanaan lockdown berdampak pada status kesehatan reproduksi wanita dikarenakan wanita yang membutuhkan layanan kesehatan reproduksi memutuskan untuk tidak melakukan kunjungan ke rumah sakit sehingga berdampak juga dengan meningkatnya jumlah pasien dengan keadaan darurat di rumah sakit. Hasil pengamatan menunjukan adanya peningkatan kematian intrauteri dan penurunan kelahiran secara spontan atau normal. (Ravaldi et al. 2020, Utri et al. 2020).

Kebijakan yang berhubungan dengan penanganan COVID-19 disusun dengan tujuan dapat mengurangi beban pada pelayanan kesehatan. Kebijakan nasional yang ditetapkan di Indonesia dalam menghadapi penyebaran pandemi COVID-19 yaitu Pembatasan Sosial Berskala Besar (PSBB). Dalam hal ini, langkah pembatasan sosial telah terbukti efektif dalam mengurangi penularan COVID-19 (Lim et al. 2020). PSBB dilakukan sebagai upaya percepatan penanganan COVID-19. Pemerintah mengatur pembatasan dalam pelaksanaan kegiatan yang kemudian disusul dengan terbitnya Instruksi Menteri Dalam Negeri (Mendagri) yang menetapkan wilayah prioritas dan mengatur pemberlakukan pembatasan kegiatan yang berpotensi menularkan COVID19. Kota Depok merupakan salah satu wilayah prioritas dalam intruksi Mendagri yang berada di wilayah Provinsi Jawa Barat. Pada saat PSBB, pemerintah daerah wajib melaksanakan dan memperhatikan ketentuan pelayanan kesehatan sebagaimana diatur dalam Undang-Undang (UU) Nomor 6 tahun 2018 tentang Kekarantinaan Kesehatan.

Penerapan pembatasan sosial pada negara berpenghasilan rendah dan menengah menunjukan dampak yang jelas pada hal pelayanan kesehatan ibu dan anak. Sebelum munculnya COVID-19, layanan kesehatan ibu yang berkualitas, berkelanjutan dan tepat waktu masih belum tersedia dan masih terdapat kesulitan untuk mengakses dan menjangkau pelayanan kesehatan bagi jutaan wanita. Saat ini, penerapan pembatasan sosial seperti adanya jam malam dan pembatasan penggunaan transportasi umum menghambat masyarakat khususnya ibu dan anak dalam mengakses layanan kesehatan. Tantangan ketersediaan alat serta pelaksanaan pencegahan infeksi pada situasi pandemi COVID-19 semakin berat sehingga dapat berdampak negatif pada penanganan kesehatan masyarakat khususnya KIA (Ashokka et al. 2020, Bantalem Yihun, Gizachew Tiruneh, Yibeltal Tebekaw, Biruhtesfa Bekele, Dessalew Emway, Nebreed Fesseha 2020). Oleh karena itu, terdapat kekhawatiran terancamnya asuhan pada ibu dan anak yang selama ini dilakukan 
dengan prinsip asuhan sayang ibu. Misalnya, dalam berbagai pedoman atau protokol, wanita tidak lagi diizinkan didampingi selama pemeriksaan kehamilan atau persalinan sebagai upaya untuk mengurangi paparan COVID-19. (Akaba et al. 2020, Ashokka et al. 2020, Hamideh Bayrampour a, ${ }^{*}$, Elena Ali b, Deborah A. McNeil c, Karen Benzies b, Glenda MacQueen d 2021, William S. Vintzileos, MD, Jolene Muscat, MD, Eva Hoffmann, MD, Duc Vo, MD, Nicole S. John, MD, Rosanne Vertichio, MSN, RN, Anthony M. Vintzileos 2020, Wu et al. 2020, Yuliani; and Aini 2020) Selanjutnya, skrining wanita (untuk demam, batuk atau kontak dengan seseorang yang terpapar COVID-19) telah diperkenalkan secara luas berdasarkan prinsip yang mendasari bahwa setiap pasien mungkin terinfeksi berakibat meningkatnya stigma terkait dengan COVID-19 sehingga membuat banyak wanita ingin menyembunyikan potensi paparan atau riwayat perjalanan mereka (Bantalem Yihun, Gizachew Tiruneh, Yibeltal Tebekaw, Biruhtesfa Bekele, Dessalew Emway, Nebreed Fesseha 2020, Molgora and Accordini 2020). Tujuan studi ini adalah untuk menilai dampak pandemi COVID19 terhadap layanan KIA dan menganalisis layanan KIA yang paling terpengaruh dalam masa pandemi COVID-19.

\section{METODE PENELITIAN}

Studi ini dilakukan di Kota Depok, Jawa Barat, terintegrasi dengan program "e-Monev untuk Pemulihan Pelayanan Kesehatan Ibu dan Anak, KB dan Gizi dari Dampak Pandemi COVID-19" yang dilaksanakan oleh Direktorat Kesehatan Keluarga, Ditjen Kesehatan Masyarakat, Kementerian Kesehatan RI bekerja sama dengan Pusat Kebijakan dan Manajemen Kesehatan FK-KMK UGM. Pelayanan KIA dalam studi ini dikelompok menjadi 4 yaitu: (i) layanan kehamilan K1, (ii) layanan kehamilan $\mathrm{K} 4$, (iii) layanan persalinan di fasilitas kesehatan, dan (iv) pemantauan tumbuh kembang balita di pos pelayanan terpadu (Posyandu). Studi menggunakan pendekatan kuantitatif dan kualitatif.

Data kuantitatif dalam studi ini menggunakan data kunjungan bulanan pada periode Januari 2019 - September 2020 dari Dinas Kesehatan (Dinkes) Kota Depok yang diambil pada Bulan September 2020. Instrumen yang digunakan adalah laporan KIA bulanan Kota Depok. Variabel yang dinilai adalah data kunjungan pertama dan keempat ibu hamil, pertolongan persalinan di fasilitas kesehatan dan data anak dibawah lima tahun (balita) yang dipantau pertumbuhan dan perkembangan. Data dikumpulkan dari melalui Aplikasi Monitoring dan Evaluasi Pelayanan Kesehatan Maternal Neonatal yang dikelola oleh Direktorat Kesehatan Keluarga, Kementerian Kesehatan RI kemudian dianalisa kenaikan dan penurunan kunjungan. Data yang terdapat dalam aplikasi merupakan data yang diinput oleh dinas kesehatan kabpuaten/kota setiap akhir bulan secara online.

Data kualitatif dalam studi ini berasal dari informan kunci untuk mendapatkan informasi mendalam terkait dampak COVID-19 yang dikumpulkan melalui wawancara mendalam dan e-survey. Informan kunci dipilih dengan kriteria merupakan kader posyandu balita di wilayah Kota Depok dan dapat menggunakan aplikasi Zoom Meeting. Pengumpulan data dilakukan dengan wawancara mendalam secara daring menggunakan aplikasi Zoom Meeting dan berjenjang yaitu pada 4 informan dari Dinkes Kota Depok kemudian 2 informan dari kader posyandu di wilayah Kota Depok. Wawancara mendalam dilakukan oleh tim monitoring dan evaluasi yaitu mahasiswa Fakultas Kesehatan Masyarakat Universitas Indonesia (FKM UI) sebanyak 2 orang yang tergabung dalam kegiatan. Pengumpulan data selanjutnya dilakukan dengan e-survey menggunakan google form yang sebelumnya sudah diuji coba pada tenaga kesehatan pelaksana di wilayah kerja Kota Depok. Kriteria tenaga kesehatan dalam studi ini merupakan tenaga kesehatan di Puskesmas wilayah Kota Depok dan tetap melakukan pelayanan di masa pandemi COVID19. Jumlah informan kunci dalam studi ini sebanyak 32 informan yang merupakan bidan pelaksana di poli KIA puskesmas.

Data kuantitatif dan kualitatif disajikan secara terpisah. Data kuantitatif disajikan dalam bentuk grafik batang kemudian dianalisa dengan membandingkan kunjungan pada bulan yang sama di tahun 2019 dan 2020. Data kualitatif disajikan dala bentuk narasi dan kutipan dari informan. Hasil analisa yaitu mengidentifikasi terjadinya kenaikan dan penurunan diperdalam dengan melakukan wawancara mendalam. Sesuai dengan protokol etika penelitian, pernyataaan kesediaan disampaikan terhadap responden dewasa sebelum pelaksanaan wawancara dan pengisian e-survey. 


\section{HASIL DAN PEMBAHASAN}

\section{Gambaran Sarana Pelayanan Kesehatan Kota Depok}

Wilayah Kota Depok memiliki sarana pelayanan kesehatan sebagai berikut (Dinas Kesehatan Kota Depok, 2020):

Tabel 1. Sarana Pelayanan Kesehatan Kota Depok

\begin{tabular}{lrr}
\hline $\begin{array}{c}\text { Fasilitas Pelayanan } \\
\text { Kesehatan }\end{array}$ & $\begin{array}{c}\text { Jumlah } \\
(\mathbf{n = 2 6 0 3})\end{array}$ & $\begin{array}{c}\text { Persentase } \\
(\mathbf{\%})\end{array}$ \\
\hline Rumah sakit umum & 18 & 0,69 \\
Rumah sakit khusus & 6 & 0,23 \\
Puskesmas rawat inap & 9 & 0,35 \\
Puskesmas non rawat & 26 & 1,00 \\
inap & & \\
Puskesmas pembantu & 5 & 0,19 \\
Klinik pratama & 182 & 6,99 \\
Klinik utama & 51 & 1,96 \\
Praktek dokter & 281 & 10,80 \\
perorangan & & \\
Praktek dokter gigi & 136 & 5,22 \\
perorangan & & \\
Praktek pengobatan & 0 & 0,00 \\
tradisional & & \\
Posyandu & 1.032 & 39,65 \\
Apotek & 198 & 7,61 \\
Toko Obat & 27 & 1,04 \\
Gudang farmasi & 1 & 0,04 \\
Produsen industri RTP & 628 & 24,13 \\
Produsen Alat & 3 & 0,12 \\
Kesehatan & & \\
\hline Sumber: Profil Kesehatan Kota Depok Tahun 2020
\end{tabular}

Peningkatan cakupan pelayanan kesehatan kepada masyarakat dilakukan dengan berbagai upaya, diantaranya melalui pemanfaatan potensi dan sumber daya yang ada di masyarakat. Upaya Kesehatan Bersumberdaya Masyarakat (UKBM) diantaranya adalah posyandu, pos binaan terpadu (posbindu), kelurahan siaga, dan lain sebagainya. Posyandu merupakan salah satu bentuk UKBM yang paling dikenal di masyarakat. Peran kader dalam penyelenggaraan posyandu sangat besar karena selain sebagai pemberi informasi kesehatan kepada masyarakat juga sebagai penggerak masyarakat untuk datang ke Posyandu dan melaksanakan Perilaku Hidup Bersih dan Sehat (PHBS). Posyandu menyelenggarakan minimal 5 program prioritas, yaitu kesehatan ibu dan anak, keluarga berencana, perbaikan gizi, imunisasi, dan penanggulangan diare. Jumlah posyandu pada tahun 2019 di Kota Depok sebanyak 1.032 dengan posyandu aktif berjumlah 966. Rasio Posyandu dengan jumlah balita tahun 2019 masih jauh dari ideal yaitu hanya 0,48 dimana rasio ideal yaitu 1 posyandu untuk 100 penduduk balita (Dinas Kesehatan Kota Depok 2020).

Pelayanan Antenatal merupakan pelayanan kesehatan oleh tenaga kesehatan profesional (dokter spesialis kandungan dan kebidanan, dokter umum, bidan dan perawat) kepada ibu hamil. Titik berat pelayanan adalah kegiatan promotif dan preventif yang hasilnya terlihat dari cakupan kunjungan pertama ibu hamil dan kunjungan ke empat ibu hamil (Dinas Kesehatan Kota Depok 2020). Berdasarkan hasil pengumpulan data, Gambar $1[\mathrm{~A}]$ menunjukkan bahwa terjadi penurunan cakupan K1 pada tahun 2020 antara Januari hingga Juni dan terdapat kenaikan pada bulan Juli sebesar 0,48\% dan Agustus sebesar 2,18\%. Pada Bulan September terjadi penurunan kembali sebesar 11,23\%. Gambar 1 [B] menunjukkan penurunan yang sama dan terdapat kenaikan pada bulan Juli sebesar 2,1\% dan Agustus sebesar 2,88\%. Pada bulan September terjadi penurunan kembali sebesar $1,55 \%$.

Hasil pengumpulan data kualitatif menunjukan terdapat informan yang mengatakan cakupan kunjungan pertama (K1), kunjungan ke empat (K4) dan persalinan di fasilitas kesehatan di Kota Depok sebelum pandemi COVID-19 berada di atas target yang ditetapkan. Hal ini seperti yang disampaikan oleh informan yang merupakan seorang Bidan di salah satu Pusat Kesehatan Masyarakat (Puskesmas) Kota Depok yaitu:

"Pelayanan KIA sebelum pandemi kunjungan rutin dilaksanakan baik untuk pemantauan maupun untuk penyuluhan" (RI)

Kunjungan masyarakat ke puskesmas juga tergolong ramai menurut petugas, seperti yang diungkapkan oleh satu penanggung jawab pelayanan KIA di Puskesmas yaitu:

"Kunjungan ibu hamil, pemantauan tumbuh kembang, pelaksanaan imunisasi sebelum pandemi sangat mudah dilakukan karena masyarakat selalu menggunakan fasilitas kesehatan terutama puskesmas untuk memeriksakan kesehatannya. Kunjungan ibu hamil setiap jadwal periksa hampir 1015 orang. Kunjungan imunisasi 20-30 bayi" (R2) 


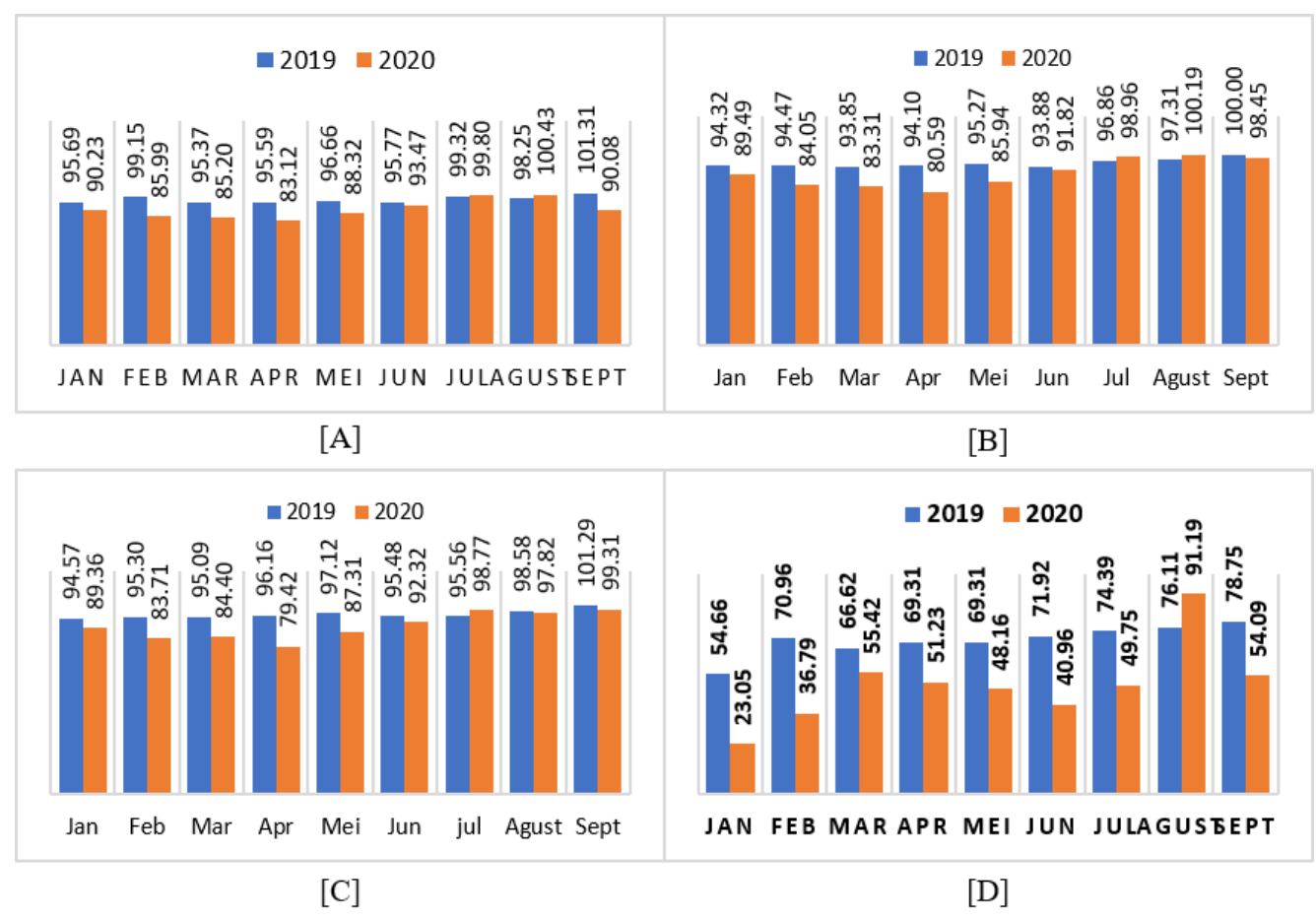

Sumber: Laporan Bulanan KIA Dinas Kesehatan Kota Depok, 2019

Gambar 1. [A] Capaian Indikator K1 Januari - September 2019 dan Januari - September 2020 di Kota Depok [B] Capaian Indikator K4 Januari - September 2019 dan Januari - September 2020 Di Kota Depok [C] Capaian Indikator Pertolongan Persalinan di Fasyankes Januari - September 2019 dan Januari - September 2020 di Kota Depok [D] Perbandingan Capaian Indikator Pelayanan Kesehatan Balita/Balita Pantau Tumbang Januari - September 2019 dan Januari - September 2020 Di Kota Depok

Sementara pada masa pandemi COVID19, cakupan K1, K4 dan persalinan di fasilitas kesehatan mengalami sedikit penurunan. Terutama di masa awal pendemi, karena sebagian besar masyarakat khawatir untuk datang ke fasilitas pelayanan kesehatan, dan karena belum adanya Aturan Yang Jelas Atau Standar operasional prosedur (SOP) mengenai pelayanan KIA saat pandemi COVID-19. Pemeriksaan kehamilan dibatasi dan hanya dilakukan dengan perjanjian. Hal ini diungkapkan oleh beberapa informan, yaitu:

"Kunjungan tidak dilakukan sampai bulan juli tetapi tetap dipantau lewat informasi dari kader atau pun pasien melalui WhatsUp Application (WA) grup dan WA pribadi" (R3)

Selama masa pandemi COVID-19, ibu tetap bersalin di fasilitas pelayanan kesehatan dan segera ke fasilitas kesehatan jika sudah ada tanda-tanda persalinan dan dilakukan rujukan berencana untuk ibu hamil yang berisiko. (Kementerian Kesehatan Republik Indonesia 2020). Gambar 1 [C] menunjukan perbandingan pertolongan persalinan di fasyankes antara tahun 2019 dan 2020 pada bulan yang sama pada bulan Januari hingga September mengalami penurunan selama masa pandemi COVID-19. Hanya bulan Juli yang mengalami kenaikan yaitu sebesar $3.21 \%$. Selama masa pandemi COVID-19 terdapat pelayanan KIA yang menurut informan tidak dapat menerapkan protokol kesehatan seperti yang diungkapkan oleh informan dari Puskesmas, yaitu:

"Ya, karena setiap kami berhadapan dan melayani pasen adalah berisiko khususnya untuk pelayanan persalinan dan KB implan baik memasang atau mencabut tidak bisa mengikuti protokol dalam hal menjaga jarak" (R4)

"Kunjungan KIA untuk ibu hamil kami batasi sehingga cakupan kunjungan menurun, untuk persalinan tetap ada pelayanan 24 jam tidak dibatasi kecuali ibu bersalin yang terpapar COVID-19 kami rujuk ke fasilitas pelayanan kesehatan yang melayani perawatan untuk ibu bersalin dengan COVID-19” (R5)

Pelayanan rutin balita sehat mengikuti kebijakan pemerintah yang berlaku di wilayah kerja dan mempertimbangkan transmisi lokal COVID-19 (Kementrian Kesehatan RI 2020). Pelaksaan pelayanan ini didasarkan pada kebijakan PSBB atau adanya kasus COVID-19 
positif pada masing-masing wilayah. Gambar 1 [D] menunjukkan bahwa capaian pemantauan tumbuh kembang jika dibandingkan antara tahun 2019 dan 2020 pada bulan yang sama pada bulan Januari hingga September, hanya bulan Agustus yang mengalami kenaikan sebesar $15,08 \%$ dan bulan lain mengalami penurunan.

Informan yang berasal dari Dinas Kesehatan menyebutkan jika capaian indikator pelayanan kesehatan balita pantau tumbuh kembang sampai dengan bulan September belum menunjukan grafik yang baik, hal ini dikarenakan sebagian besar posyandu belum melakukan pelayanan dan sebagian besar masyarakat serta kader kesehatan tidak berani untuk datang ke posyandu. Didukung dengan pernyataan informan yang merupakan kader posyandu bahwa posyandu tidak dilaksanakan pada Bulan April dan Mei, semua kegiatan posyandu terhenti. Pada Bulan Juni terdapat surat dari gugus tugas COVID-19 jika boleh membuka kegiatan posyandu dengan protokol kesehatan. Selam ini kegiatan konseling gizi tetap berjalan dengan cara online, terdapat kegiatan tatap muka dengan menggunakan janji temu melalui Whatsapp (WA).

Informan yang merupakan kader posyandu menyampaikan suasana berlangsungnya pelaksanaan posyandu di lingkungannya, sebagai berikut:

"Kader semangat, ibu-ibu ada yang antusias ada juga yang takut, semua kader kesehatan masuk ke satuan tugas COVID19, masker dan handsanitizer didukung oleh RW. Posyandu dilakukan di rumah kader yang luas. Menimbang dilakukan boleh kapan saja datang ke rumah kader tersebut. Harapannya puskesmas memberikan penjelasan yang jelas terkait COVID-19 jadi biar paham dan bisa menyampaikan ke masyarakat dengan benar" (R6).

Informan lain menyampaikan mengenai pelaksanaan pemantauan pertumbuhan dan perkembangan balita, yaitu:

\footnotetext{
"Untuk pemantauan tumbuh kembang anak dengan menggalakan Stimulasi Deteksi dan Intervensi Dini Tumbuh Kembang dan memanfaatkan buku KIA meskipun ada kekurangan buku KIA untuk kader dan guru PAUD sebagai pegangan, untuk kematian ibu dan pemantauan ibu hamil, imunisasi berkoordinasi dengan kader lewat group WA dimasing2 daerah binaan, dan berkerja
}

$$
\begin{aligned}
& \text { sama dengan mitra jejaring di wilayah kerja } \\
& \text { untuk mengurai kepadatan dalam } \\
& \text { pelayanan" }(R 7) \text {. }
\end{aligned}
$$

Hasil penelitian menggambarkan pelayanan KIA sebelum dan selama pandemi di Kota Depok, Provinsi Jawa Barat. Tidak dapat dipungkiri, jika pandemi COVID-19 merupakan tantangan terhadap ketahanan sistem kesehatan di seluruh dunia. Pada negara berpenghasilan rendah dan menengah, pandemi COVID-19 menyebar dengan cepat ditengah masalah kesehatan endemik seperti HIV, TBC, malaria, malnutrisi dan tingkat kematian yang masih tinggi. Hal ini terjadi dalam konteks infrastruktur kesehatan yang lemah yang hampir tidak dapat mengatasi tantangan kesehatan yang ada (Menendez et al. 2020).

Pada masa krisis, negara dapat memberikan batasan dalam pemenuhan beberapa hak masyarakat untuk alasan keamanan, keselamatan atau manajemen sumber daya dalam keadaan darurat. Namun, mempertahankan hak atas layanan kesehatan ibu dan anak merupakan hal yang sangat penting untuk mencegah kecacatan dan kematian yang lebih banyak (Djalante et al. 2020, Jolivet et al. 2020, Lindberg et al. 2020). Indonesia mengandalkan pembatasan interaksi fisik atau pembatasan sosial untuk memperlambat penyebaran COVID-19. Berbagai rekomendasi dan kebijakan yang dikeluarkan kemudian mempengaruhi berbagai aspek pelayanan kesehatan masyarakat di Indonesia, diantaranya pelayanan KIA.

Cakupan K1 dan cakupan K4 merupakan indikator yang dapat mengetahui jangkauan pelayanan antenatal dan cakupan pelayanan antenatal secara lengkap, yang menggambarkan tingkat perlindungan ibu hamil di suatu wilayah, di samping menggambarkan kemampuan manajemen ataupun kelangsungan program KIA. Berdasarkan hasil data kuantitatif dan kualitatif, pelayanan KIA dalam gedung seperti pemeriksaan rutin ibu hamil (K1 dan K4), persalinan di fasyankes dan pemeriksaan balita mengalami penurunan cakupan akibat pandemi COVID-19. Hal ini dapat dikarenakan pada masa pandemi pemeriksaan atau kunjungan ibu hamil dilakukan dengan cara membuat janji terebih dahulu; anjuran untuk menunda pemeriksaan kehamilan trimester II atau dapat dilakukan dengan cara tele konsultasi kecuali terdapat tanda bahaya kemudian pemeriksaan kehamilan trimester III harus dilakukan 1 bulan 
sebelum taksiran persalinan; memanfaatkan buku KIA sebagai media KIE dan memanfaatkan media komunikasi untuk konsultasi; ibu hamil, keluarga dan kader berperan aktif dalam memantau tanda bahaya kehamilan (Kementerian Kesehatan Republik Indonesia 2020).

Kegiatan KIA luar gedung seperti balita ditimbang dan dipantau tumbuh kembang juga mengalami penurunan cakupan. Cakupan balita ditimbang dan dipantau tumbuh kembang pada bulan Maret 2020 hanya sekitar 22,45\% balita dan menurun jika dibandingkan dengan cakupan bulan Januari 2020 sebesar 77\%. Data ini tidak dapat dibandingkan dengan data pada bulan Februari dan Agustus pada tahun yang sama karena merupakan bulan penimbangan balita yang diintegrasikan dengan pemberian vitamin A. Apabila tidak ada program pemulihan untuk cakupan balita ditimbang, dapat berdampak pada peningkatan jumlah balita dengan kondisi gizi buruk di Kota Depok. Hal ini dapat disebabkan karena Depok merupakan salah satu wilayah yang menerapkan PSBB. Pelayanan rutin balita sehat mengikuti kebijakan pemerintah yang berlaku di wilayah kerja dan mempertimbnagkan transmisi COVID-19.

Pada wilayah yang menerapkan PSBB atau terdapat kasus COVID-19 positif maka pelayanan balita di posyandu ditiadakan, pemantauan tumbuh kembang mandiri di rumah dengan buku KIA (kunjungan rumah untuk balita berisiko), pelayanan imunisasi di fasyankes dengan janji temu. Berdasarkan pedoman yang dikeluarkan oleh gugus tugas untuk wilayah PSBB atau kasus COVID-19 positif, pelayanan balita di posyandu di tunda, pemantauan pertumbuhan dan perkembangan dilakukan mandiri di rumah dengan buku KIA dan untuk balita berisiko dengan tele-konsultasi atau janji temu atau kunjungan rumah, pelayanan imunisasi, vitamin A di fasilitas kesehatan dengan janji temu dan pelaksanaan pemberian obat pencegahan massal (POPM) cacingan ditunda. Cakupan penimbangan balita saat ini $31.91 \%$, masih jauh dari sebelum masa pandemi yaitu sebesar $68.42 \%$. Hal ini tentunya selain membuat standar pelayanan kesehatan balita tidak dapat tercapai, juga menimbulkan risiko dampak jangka pendek dan panjang terhadap kesehatan, kesejahteraan, perkembangan, dan masa depan anak (Saepuddin et al. 2018, Umur 2019). Dengan pembatasan terhadap aktifitas perekonomian dan perdagangan, dapat mengakibatkan berkurang pendapatan rumah tangga, ketidakmampuan keluarga dalam membiayai kebutuhan nutrisi anak, yang meningkatkan risiko anak menjadi kurus dan kekurangan gizi mikro (Jannah and Maesaroh 2018, Windiyati 2020). Sementara dengan kegiatan penimbangan balita yang dilaksanakan sangat terbatas, deteksi dini terhadap kekurangan gizi balita, yang dapat dipantuan dari 2 kali berturut-turut tidak naik berat badannya, sangat sulit dilakukan.

\section{KESIMPULAN DAN SARAN}

\section{Kesimpulan}

Kesimpulan dari studi ini adalah terjadi penurunan pada cakupan K1 dan K4, cakupan persalinan di fasilitas kesehatan dan pemantauan tumbuh kembang balita. Layanan KIA yang paling terpengaruh pada pandemi COVID-19 adalah pemantauan tumbuh kembang balita. Hal ini disebabkan karena adanya pembatasan sosial serta larangan berkumpul dalam keolompok yang mengakibatkan keramaian. Sehingga posyandu yang merupakan kegiatan berbasis masyarakat harus ditunda pelaksanaannya.

\section{Saran}

Perluasan akses terhadap pelayanan kesehatan dengan memobilisasi kader kesehatan yang sudah diberi pengetahuan tambahan seperti cara melakukan penimbangan yang tepat dan melakukan KIE kepada masyarakat. Serta peningkatan aktifitas kegiatan promosi dan pencegahan yang bersifat virtual/online kepada masyarakat oleh petugas Puskesmas.

\section{UCAPAN TERIMAKASIH}

Diucapkan terimakasih kepada Direktorat Kesehatan Keluarga Kementerian Kesehatan RI dan Pusat Kebijakan dan Manajemen Kesehatan FK-KMK UGM yang telah memberikan akses data pada Aplikasi Monitoring dan Evaluasi Pelayanan Kesehatan Maternal Neonatal, sehingga Analisa data dapat dilaksanakan.

\section{DAFTAR RUJUKAN}

1] Akaba G, Dirisu O, Okunade K, Adams E, Ohioghame J, Obikeze O, Izuka E, Sulieman $\mathrm{M}$ and Edeh M (2020) Impact of COVID-19 on utilization of maternal, newborn and child health services in Nigeria: protocol for a country-level mixed-methods study. F1000Research 9: 1106.

2] Ashokka B, Loh MH, Tan CH, Su LL, Young BE, Lye DC, Biswas A, Illanes SE 
and Choolani M (2020) Care of the pregnant woman with coronavirus disease 2019 in labor and delivery: anesthesia, emergency cesarean delivery, differential diagnosis in the acutely ill parturient, care of the newborn, and protection of the healthcare personnel. American Journal of Obstetrics and Gynecology. Elsevier Inc. 223(1): 6674.e3. Available at: https://doi.org/10.1016/j.ajog.2020.04.005.

3] Bantalem Yihun, Gizachew Tiruneh, Yibeltal Tebekaw, Biruhtesfa Bekele, Dessalew Emway, Nebreed Fesseha WB (2020) Immediate Impacts of COVID-19 Pandemic on Essential MNCH Services in Selected Health Facilities in Ethiopia Methods. Jsi Resources: Publications 19. Available at: https://publications.jsi.com/JSIInternet/Inc/ Common/_download_pub.cfm?id=23681\&1 $\mathrm{id}=3$.

4] Baumann S, Gaucher L, Bourgueil Y, Saintlary O, Gautier S and Rousseau A (2021) Adaptation of independent midwives to the COVID-19 pandemic: A national descriptive survey. Elsevier Ltd 94(December 2020).

5] Dinas Kesehatan Kota Depok (2020) Profil Kesehatan Kota Depok 2019. Profil Dinas Kesehatan Kota Depok 1-116. Available at: http://dinkes.depok.go.id/.

6] Djalante R, Lassa J, Setiamarga D, Sudjatma A, Indrawan $M$, Haryanto $B$, Mahfud C, Sinapoy MS, Djalante S, Rafliana I, Gunawan LA, Surtiari GAK and Warsilah H (2020) Review and analysis of current responses to COVID-19 in Indonesia: Period of January to March 2020. Progress in Disaster Science 6: 100091.

7] Hamideh Bayrampour a,*, Elena Ali b, Deborah A. McNeil c, Karen Benzies b, Glenda MacQueen d ST (2021) Effects of coronavirus 19 pandemic on maternal anxiety during pregnancy: a prospectic observational study. Women and Birth. Elsevier Ltd 4(1): 1-11. Available at: https://doi.org/10.1016/j.jadr.2021.100085 (accessed 12/06/21).

8] Jannah M and Maesaroh S (2018) Hubunga Tingkat Pendidikan Ibu dengan Status Gizi Balita di Posyandu Bangunsari Semin Gubung Kidul Tahun 2014. Jurnal Kebidanan Indonesia 42-52.
9] Jolivet RR, Warren CE, Sripad P, Ateva E, Mitchell K, Hacker HP, Sacks E, Langer A, Jolivet RR, Warren CE, Sripad P, Ateva E, Mitchell K, Hacker HP and Sacks E (2020) Upholding Rights Under COVID-19: The Respectful Maternity Care Charter. .

10] Kementerian Kesehatan Republik Indonesia (2020) Pedoman Bagi Ibu Hamil, Bersalin, Nifas dan Bayi Baru Lahir di Era Pandemi Covid-19 Revisi 1.

11] Kementrian Kesehatan RI (2020) Panduan Pelayanan Kesehatan Balita Pada Masa Tanggap Darurat COVID-19. Kementrian Kesehatan RI 1-30. Available at: https://covid19.go.id/p/protokol/panduanpelayanan-kesehatan-balita-pada-masapandemi-covid-19.

12] Lim LM, Li S, Biswas A and Choolani M (2020) Coronavirus disease 2019 (COVID19) pandemic and pregnancy. The American Journal of Obstetrics \& Gynecology. Elsevier Inc. 222(6): 521-531. Available at: https://doi.org/10.1016/j.ajog.2020.03.021.

13] Lindberg L, VandeVusse D, Mueller A, Kirstein J and Mariell (2020) Early Impacts of the COVID-19 Pandemic: Findings from the 2020 Guttmacher Survey of Reproductive Health Experiences. (June). Available at: www.guttmacher.org.

14] Lindholt JS and Søgaard R (2020) Universal Screening for SARS-CoV-2 in Women Admitted for Delivery. 2163-2164.

15] Menendez C, Gonzalez R, Donnay F and Leke RGF (2020) Avoiding indirect effects of COVID-19 on maternal and child health. The Lancet Global Health. The Author(s). Published by Elsevier Ltd. This is an Open Access article under the CC BY 4.0 license 8(7): e863-e864. Available at: http://dx.doi.org/10.1016/S2214109X(20)30239-4.

16] Molgora S and Accordini M (2020) Motherhood in the Time of Coronavirus: The Impact of the Pandemic Emergency on Expectant and Postpartum Women's Psychological Well-Being. 11(October): 116.

17] Moyer C, Compton S, Kaselitz E and Muzik M (2020) Pregnancy-related anxiety during COVID-19: A nationwide survey of 2,740 pregnant women. .

18] Ravaldi C, Wilson A, Ricca V, Homer $C$ and Vannacci A (2020) Pregnant women voice 
their concerns and birth expectations during the COVID-19 pandemic in Italy. Women and Birth. Australian College of Midwives 34(4): 335-343. Available at: https://doi.org/10.1016/j.wombi.2020.07.00 2.

19] Saepuddin E, Rizal E and Rusmana A (2018) Posyandu Roles as Mothers and Child Health Information Center. Record and Library Journal 3(2): 201.

20] Saputri NS, Anbarani MD, Toyamah $N$ and Yumna A (2020) Dampak Pandemi Covid19 Kesehatan Ibu Dan Anak (Kia): Pada Layanan Gizi Dan Studi Kasus Di Lima Wilayah Di Indonesia. Smeru 5(5): 1-8. Available http://smeru.or.id/id/content/dampakpandemi-covid-19-pada-layanan-gizi-dankesehatan-ibu-dan-anak-kia-studi-kasus-dilima.

21] Umur B (2019) Analisis Faktor Keteraturan Kunjungan Posyandu Balita Dan Status Gizi Balita Berdasarkan Berat Badan/Umur (Danik Riawati, Ajeng Novita Sari) 137. 10(1): 137-146.

22] Utri $C D$, Manzoni E, Cipriani $S$, Acqua $A D$, Barbara G, Parazzini $F$ and Kusterman A (2020) Effects of SARS Cov-2 epidemic on the Obstetrical and Gynecological Emergency Service accesses. What happened and what shall we expect now? (September).

23] Vintzileos WS, Muscat J, Hoffmann E, Vo D, John NS, Vertichio R and Vintzileos AM (2020) Screening all pregnant women admitted to Labor and Delivery for the virus responsible for COVID-19. American Journal of Obstetrics and Gynecology. Elsevier Inc. Available at: https://doi.org/10.1016/j.ajog.2020.04.024.
24] William S. Vintzileos, MD, Jolene Muscat, MD, Eva Hoffmann, MD, Duc Vo, MD, Nicole S. John, MD, Rosanne Vertichio, MSN, RN, Anthony M. Vintzileos M (2020) Impact of the COVID-19 Pandemic on Family Planning and Ending Gender-based Violence, Female Genital Mutilation and Child Marriage. Progress in Disaster Science. The Author(s). Published by Elsevier Ltd. This is an Open Access article under the CC BY 4.0 license 6(2): 98. Available at: https://www.unfpa.org/sites/default/files/res ource-pdf/COVID-

19_impact_brief_for_UNFPA_24_April_20 20_1.pdf.

25] Windiyati (2020) Pengaruh Pengetahuan Dan Pola Asuh Ibu Terhadap Status Gizi Balita Di Posyandu Tunas Melati Desa Limbung Kecamatan Sungai Raya Kabupaten Kubu Raya Tahun 2020 Akademi Kebidanan Panca Bhakti Pontianak Email Korespondensi : akbid. 10: 487-501.

26] Wu Y, Zhang C, Liu H, Duan C, Li C, Fan J, Li H, Chen L, Xu H, Li X, Guo Y, Wang Y, Li X, Li J, Zhang T, You Y, Li H, Yang S, Tao X, Xu Y, Lao H, Wen M, Zhou Y, Wang J, Chen Y, Meng D, Zhai J, Ye Y, Zhong Q, Yang X, Zhang D, Zhang J, Wu X, Chen W, Dennis CL and Huang H feng (2020) Perinatal depressive and anxiety symptoms of pregnant women during the coronavirus disease 2019 outbreak in China. American Journal of Obstetrics and Gynecology. Elsevier Inc. 223(2): 240.e1-240.e9. Available at: https://doi.org/10.1016/j.ajog.2020.05.009.

27] Yuliani; DR and Aini FN (2020) Kecemasan Ibu Hamil Dan Ibu Nifas Pada Masa Pandemi COVID-19 Di Kecamatan Baturraden. 2(2). 